\title{
11. Regionalism that respects localism: the Anmatjere Community Government Council and beyond
}

\section{Will Sanders}

\section{Introduction}

The Anmatjere Community Government Council (ACGC) in central Australia was established in 1993 as part of a push by the Northern Territory (NT) Government towards larger regional, multi-settlement groupings within its emerging local government system. Fifteen years on, as part of another such push, ACGC is about to be amalgamated into a much larger Central Desert Shire. The shire, which will begin operations during 2008, will merge ACGC with five other local governing bodies and cover a population some four times ACGC's current constituency.

This chapter reflects on the history of ACGC within the NT local government system and on ideas of regionalism and localism. It argues that ACGC has been a reasonably successful experiment in regional, multi-settlement local government, and that this is partly because it has respected and built on single-settlement localism. The chapter will discuss how the early constitutional design of ACGC respected such localism and how that respect has developed and endured since, albeit at times under stress. I will also argue that this respect for single-settlement localism points the way forward for local government in the NT under the new larger shires arrangement. Regionalism must build on localism, rather than devalue or disparage it.

\section{The emergence of ACGC}

The Anmatjere region sits astride the Stuart Highway about $200 \mathrm{~km}$ north of Alice Springs. The name derives from the region's Aboriginal language, which is still widely spoken among the predominantly Aboriginal population of 1,000 or more people. ${ }^{1}$ European settlement in the area dates back to the 1870s, when a repeater station on the Overland Telegraph Line was established at Ti Tree well. Pastoralism followed in the early years of the twentieth century, with most land then being leased to settlers for pastoral purposes. In later years, some small horticultural blocks were also developed by settlers, along with a roadhouse or two. The only town in the region is Ti Tree, gazetted in 1980, straddling the

\footnotetext{
${ }^{1}$ The 2006 Census enumerated 966 usual residents in the Anmatjere area, 88 per cent of whom identified as Indigenous and 56 per cent of whom listed Anmatyerr as the language spoken at home. Another 12 per cent each spoke Warlpiri and Arrernte at home.
} 
Stuart Highway on a five mile square (ca. $64 \mathrm{~km}^{2}$ ) parcel of land, which was formerly the old telegraph reserve.

In the late 1970s, the Ti Tree Station pastoral lease surrounding the town was acquired for Aboriginal people by the Commonwealth's Aboriginal Land Fund Commission. In the early 1980s, a successful land claim converted this lease to Aboriginal freehold, as the Ahakeye Land Trust. While this might suggest that the region fared quite well in the early years of the Commonwealth's land rights system for Aboriginal people in the NT, this was not the predominant perception among local Aboriginal people. In the late 1980s and early 1990s, a movement developed among Aboriginal people in Anmatjere for a breakaway regional land council, separate from the larger Central Land Council based in Alice Springs. The Commonwealth Minister for Aboriginal Affairs was not convinced that the requirements for such a breakaway land council had been met, and did not support the move (Morton 1994). However, the NT Government, through its local government Minister, saw the opportunity to support a regional local government in the area, and thus the ACGC emerged.

At self-government in 1978, the NT had just four local governments in its major urban centres. During the 1980s, the NT Government encouraged the development of local governments in smaller urban centres and outlying areas, under the Community Government provisions of its Local Government Act (Coburn 1982; Phegan 1989). At first, as one commentator of the time noted, the approach was 'laissez fare' and the pattern that began to emerge was of small, single-settlement local government incorporations (Wolfe 1989). However, in time, the NT Government became more directive and promoted the idea of larger, regional, multi-settlement incorporations. The first of these to emerge was Yugul Mangi Community Government Council in southeast Arnhem Land in 1988, which brought together eight non-contiguous parcels of land and their associated discrete Aboriginal communities. ${ }^{2}$ The second, in 1993, was ACGC, which was proudly proclaimed by the local government Minister in the Legislative Assembly of the Northern Territory (LANT) as the twentieth community government council (LANT 1993a: 8583). The Minister also noted in the Assembly a month later that the ACGC's first meeting had been held and that Eric Panangka had been elected as chair (LANT 1993b: 8854). As well as being prominent in the movement for a breakaway land council, Panangka had been a Country Liberal Party (CLP) candidate for the Legislative Assembly seat of Stuart in the 1991 elections. So, there were clearly quite close and amiable connections between the CLP Government of the time and the emerging ACGC.

In its 1993 incarnation, ACGC brought together nine wards containing discrete Aboriginal communities. Three of these wards were the Ahakeye Land Trust,

\footnotetext{
2 Yugul Mangi CGC was dismissed in 2001 and reformed in 2003 to cover one larger land area. Like ACGC, it is now about to disappear into a much larger shire.
} 
divided into western, central and eastern portions, each of which had one significant discrete Aboriginal settlement on it. Around this large central block of incorporated land were six other wards on much smaller land parcels. These were Aboriginal living area excisions from surrounding pastoral leases, measured in hectares rather than square miles (see Fig. 11.1). As well as having very different land bases, these nine wards also had very different population bases, with some settlements having over 200 residents and some less than 50 . However, in a classic federal move, each of the wards was given an equal representation of two potential members on the council, irrespective of its population size. Another interesting constitutional provision was that a quorum for council meetings required a member to be present from every ward that currently had members. Like the ward representation rule, this very high quorum rule indicated a guarded regional federalism that had considerable respect for the autonomy of its constituent parts.

\section{Fig. 11.1 Area and wards of the Anmatjere Community Government Council}

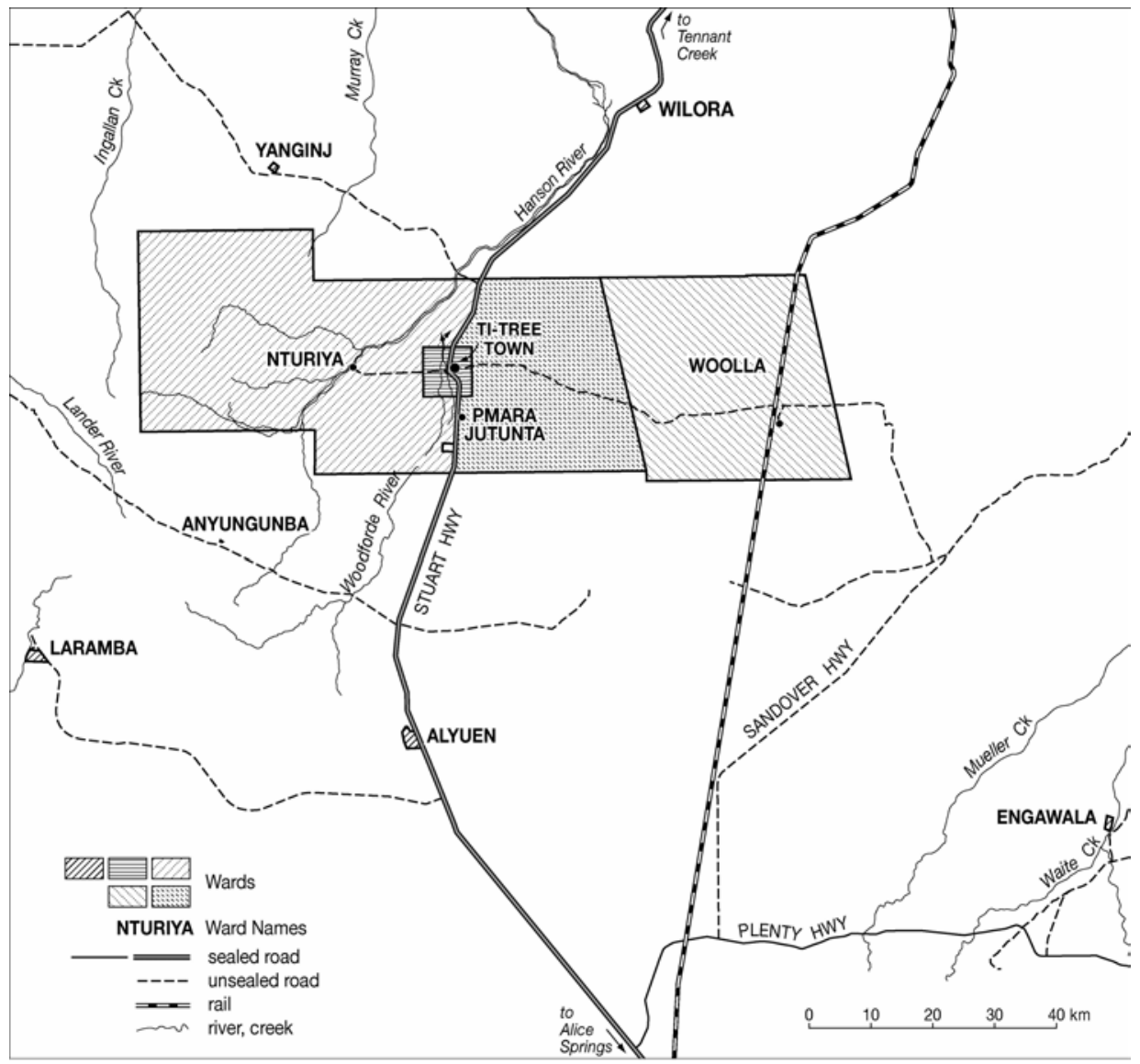


This original ACGC in 1993 was an all-Aboriginal affair. Settler interests in the region, such as pastoralists, roadhouse residents, horticulturalists and Ti Tree town residents, were all left outside the scheme, on about 90 per cent of the region's land area, covered by nine or 10 pastoral leases and other non-Aboriginal land tenures. However, the NT Government's intention from the outset was at least to bring the residents and land area of Ti Tree town into the scheme. The move to do this in 1995 met with considerable resistance from the existing organisational guardian of the town, the Ti Tree Progress Association. In previous years, under the dominance of settler interests, this organisation had developed town facilities like a park and an airstrip. Now, these assets were to become the responsibility of ACGC, and Ti Tree town residents were being asked to throw in their lot as one additional ward, with two members, within a predominantly Aboriginal local government. The one concession to Ti Tree's rather different status as a small open roadside town, rather than a discrete Aboriginal settlement, was the residence requirements for voting or standing for office. In this ward, the requirements were to be just three months before the closure of the rolls, rather than one year in the previous three years as in the other wards. This reflected the fact that many people from elsewhere moved through Ti Tree in quite short periods of time as public sector employees at the school, the health clinic, the police station or in ACGC.

At the time the Ti Tree town ward was included in ACGC in 1995, there was some controversy over who was on the electoral roll for the ward. The Labor member for Stuart, and Opposition Leader in the NT Legislative Assembly, suggested that some Aboriginal town residents who had supported the inclusion might have been improperly removed from the roll, which only had 27 eligible voters on it. Controversy was also aroused by the fact that the Council Clerk of the ACGC was nominating to be an elected member for the Ti Tree town ward, which the Opposition Leader saw as a significant conflict of interest (LANT 1995a: 4680, 1995b: 4796). ${ }^{3}$

Clearly, the early years of ACGC were quite contested and difficult. One source of this contestation was the attempt to mix Indigenous and settler town interests. Another, however, was the multi-settlement nature of the Indigenous regionalism. This required council members to travel into town once a month for meetings from settlements which were, in two cases, up to $150 \mathrm{~km}$ away, and in five cases, $50 \mathrm{~km}$ away (see Fig. 11.1). Council members pushed for vehicles to enable them to get to meetings and to attend to constituency matters in between times. The inaugural Council Clerk responded to this pressure by leasing a number of vehicles for the use of members under standard public sector arrangements. This

\footnotetext{
3 The ACGC Clerk was successful in this bid, but in time the NT Government amended its Local Government Act to say that council employees could only stand for elected office with the permission of the minister. Subsequently, the policy followed was generally only to give such permission to non-managerial employees, and not to council clerks or other significant managerial employees.
} 
worked well until the three year term of these leases was looming, and the vehicles had done far more kilometres and were in far worse condition than the terms of the leases allowed. Due to lease penalties that would need to be paid, in late 1996 and early 1997, ACGC was facing a financial overrun of some $\$ 150,000$. The Council Clerk chose, at that time, to vacate his position, leaving the problem of bringing in the vehicles and dealing with the financial overrun to his deputy and successor.

Elsewhere, I have written about how this first Council Clerk is, in fact, well remembered and how it is difficult to judge his vehicle leasing arrangements entirely adversely (Sanders 2006a). At one level, leasing vehicles was innovative and entrepreneurial management, at another, somewhat naïve and un-strategic, at least in the longer term. At base, the episode illustrated a problem of small scale organisation that I have labeled 'isolated managerialism', and which the NT Government's push towards larger, regional local governments was, at least partly, intended to overcome (Sanders 2005, 2006a). At this point, therefore, I will briefly turn back to the NT Government and its promotion of larger, regional, multi-settlement local governments before returning to pick up the story of ACGC in later years.

\section{Actively promoting voluntary regionalism: the Northern Territory Government 1999-2005}

In early 1999, The Hon. Loraine Braham, the local government Minister in the long-serving CLP NT Government, announced to the Legislative Assembly a 'reform and development' agenda for local government. She argued that while the development of community government over the previous 20 years had been 'useful in bringing small remote communities into the wider local government industry', it was 'now time to make changes ... which build upon the knowledge and experience' of those years. She noted that of the Territory's then 68 local governments, many had 'populations of around 300 people' and that in these situations 'the amount required for even a basic level of administration impacts seriously on the amount of money available for services'. She also noted that some of these local governments 'face continuing difficulties in attracting sufficient numbers of qualified, competent and ethical staff' and that 'many fail to do so'. Many 'current councils', she argued are 'simply too small' to allow 'for the achievement of any economies of scale' (LANT 1999: 2769-70).

Braham detailed the way in which numbers of local government councils were being reduced in places like Victoria and Tasmania, and said that it was 'the Government's view that there should eventually be less councils in the Territory' as well. She insisted that 'no minimum population' was being 'set' but argued that 'councils with a population of less than about 2,000 people encounter greater difficulties in maintaining adequate levels of administration and service delivery over the longer-term'. However, she also noted that: 
a movement towards larger, more sustainable councils does not mean that the Government is seeking to deny small, remote communities the opportunity to make decisions at the local level ... It is essential, therefore, that in developing constitutions for larger councils, the capacity is maintained, to an appropriate degree, for smaller communities to make decisions specific to them (LANT 1999: 2771).

In many ways, therefore, while the NT Government was clearly pushing strongly for larger, regional, multi-settlement local governments in 1999, it was also still acknowledging respect for single-settlement localism.

The most obvious product of this 1999 policy push was the Tiwi Islands Local Government, which emerged in 2001, combining three former community government councils (Campbell 2001). In central Australia, however, there was little evident change, and ACGC remained the one clear instance of a regional, multi-settlement local government.

After the election of a Labor Government in the NT in August 2001, the local government portfolio was taken on by the Territory's first Aboriginal Minister, The Hon. John Ah Kit. In March 2002, in a Ministerial statement to the Legislative Assembly, The Hon. Ah Kit indicated that he would be re-casting the local government reform and development agenda 'to look at regional governance issues relating to specific service delivery functions, rather than looking narrowly at the amalgamation of Community Government Councils' (LANT 2002b: 1112). Fourteen months later, The Hon. Ah Kit announced a Building Stronger Regions - Stronger Futures package, which did indeed cast regional development somewhat more broadly, as economic development, local government and other service delivery (Ah Kit 2003). However, in the local government area, the new reform agenda also essentially came down to voluntary regional up-scaling and amalgamation, albeit under the new label of 'regional authority'. In August 2003, Ah Kit told the Legislative Assembly of the Northern Territory that:

the creation of regional authorities will only occur where it is the wish of the communities involved to adopt this model for service delivery. The concept of regional authorities that we propose is straightforward. They will be established under the Local Government Act. The constitutions of regional authorities will give them power to govern, and make by-laws for the area they cover.

We are not inventing a new tier of government, but we are creating the capacity for councils to voluntarily come together for improved service delivery (LANT 2003: 4861)

The Hon. John Ah Kit identified that two new regional groupings had already emerged in 2003, the Thamarrurr Regional Council at Wadeye, 350km southwest of Darwin, and the Nyirranggulang Mardrulk Ngadberre Regional Council to 
the east of Katherine. One other grouping was also being discussed as a possibility in the West MacDonnell Ranges area of central Australia (LANT 2003: 4862; see also NT Government 2003: 12). However, as it turned out, this last never came to fruition.

Voluntary regional up-scaling of remote area local governments seemed to be a fairly slow and variable process. Some in the tropical 'top end' of the NT were slowly embracing the idea, but the arid 'centre' seemed more problematic and resistant.

\section{ACGC around the millennium: centre/periphery tensions}

During these years around the millennium, ACGC was not under particular pressure from the NT Government to be reformed. Along with Yuendumu, ACGC was the only remote area local government in central Australia that could claim a population of over 1,000 . So, the reform effort was in many ways directed much more to the 20 or so other such local governing bodies in central Australia that serviced populations of well under 1,000 (see Sanders 2006b). ACGC's challenge, either side of the millennium, once it had recovered from its financial overrun of 1996-97, seemed to be managing emerging centre/periphery tensions.

Once Ti Tree town had been added as a ward in 1995, it became very clear that the town was becoming the centre of ACGC operations. Housing began to be built there for managerial staff and a new, quite substantial office complex and council chambers began to be planned and developed there, which was finally opened in 2002. ACGC also developed a new Aged Care Day Centre in Ti Tree during these years, as well as having its major works yard there (see Fig. 11.2).

With all this development of ACGC infrastructure occurring in Ti Tree town, there were clearly times when some of the council members and their constituents from the outlying discrete Aboriginal settlement wards wondered whether they were getting an appropriate share of the ACGC's attention and resources. The two most outlying and quite populous settlements, Laramba to the southwest and Engawala to the southeast, had little to gain from infrastructure and services being developed in Ti Tree town, as they were the best part of $150 \mathrm{~km}$ and two hours drive away (see Fig. 11.1). Each maintained their own community association and office, and ran a Community Development Employment Project (CDEP) for local people separate from ACGC. ${ }^{4}$ Also, their power and water systems were stand alone and not always run by ACGC. So, there were several times when Laramba, in particular, felt it was gaining little from ACGC and threatened to break away with a grouping of settlements to its west. At one

\footnotetext{
4 CDEP is often referred to as the Indigenous work-for-the-dole scheme. However, CDEP pre-existed the general Australian Government 'Work for the Dole' scheme, introduced in 1996, by almost 20 years, and there are some pertinent differences between the two. Perhaps the most important is that CDEP participants are employees of the organisation running CDEP, whereas Work for Dole participants are Centrelink payment recipients, who are directed to undertake an activity with a placement organisation.
} 
point, Laramba's secession ambitions were even discussed in the NT Legislative Assembly (LANT 2002a: 934).

\section{Fig. 11.2 Ti Tree town and Creek Camp}



Some of the settlements closer to Ti Tree also had cause to wonder about the efficacy of the ACGC arrangement during these years. Three settlements $50 \mathrm{~km}$ from Ti Tree on dirt roads, Yanginj, Woolla and Anyungunba, had just basic water, electricity and housing services managed by ACGC, and were having trouble retaining residents. As numbers of residents fell, so did service levels. Two other settlements $50 \mathrm{~km}$ from Ti Tree, but adjacent to the highway, Alyuen and Wilora, seemed to be doing better at retaining their residents, but in some sense this was not primarily due to ACGC services. Alyuen had access to a nearby roadhouse for stores, and Wilora had access to a small pastoral station store, a 
CDEP run independently of ACGC, and a small school. Again, ACGC really only oversaw the water, electricity and housing in these communities.

The two closest settlements to Ti Tree, Pmara Jutunta and Nturiya, were experiencing different issues again. Already among the more populous settlements in the regional grouping, their populations seemed if anything to be growing, but at the same time, their service levels seemed to be falling. Being only $10 \mathrm{~km}$ and $17 \mathrm{~km}$ respectively from Ti Tree, there had been a judgment made by the ACGC administration in previous years that the residents of these two settlements could use the ACGC office in Ti Tree and no ACGC office presence was maintained in Pmara Jutunta or Nturiya. While this may have seemed acceptable for a while, when the community store run by the Aboriginal pastoral company closed at Nturiya early in 2002, that settlement was effectively left without any local place for even basic administrative business. Nturiya was now simply a housing estate from which people were obliged to commute to Ti Tree for virtually all services. Pmara Jutunta, by contrast, still had a community store, although it was becoming run down. ${ }^{5}$

While the decline of store services in Nturiya and Pmara Jutunta was not the direct responsibility of ACGC, when combined with the lack of ACGC offices in the settlements it did not augur well. Service levels generally in these two more populous settlements seemed to be contracting back to just housing, water and electricity, as in some of the less populous settlements $50 \mathrm{~km}$ out of town. This contraction of service levels in the discrete Aboriginal settlements surrounding Ti Tree was clearly going to have ramifications for ACGC as the local governing body, particularly when contrasted with ACGC's growing level of infrastructure in Ti Tree town. There were thus, it seemed, some centre-periphery tensions developing in ACGC around the turn of the millennium, which needed to be managed.

\section{Building relationships: working with Anmatjere Community Government Council 2004-06}

When Sarah Holcombe and I approached ACGC to be part of the Indigenous Community Governance Project (ICGP) in the early months of 2004, our arrival coincided with that of a new Chief Executive Officer (CEO). The appointee was an officer of the NT local government department who, towards the end of his career, wanted to take the opportunity to show that a regional, multi-settlement local government like ACGC could work. He was open to our involvement and, as a new arrival, was not at all defensive about the existing situation at ACGC. We attended our first council meeting in June 2004, and council too seemed open to our involvement, though somewhat tentative.

\footnotetext{
${ }^{5}$ The Pmara Jutunta community store ended up closing in mid 2006.
} 
Two months later we heard from the CEO that council had been dismissed. The reason was that members from some of the nine wards that then had members were not turning up to monthly meetings and the rules clearly stated that if council did not meet its quorum rule for two consecutive meetings it was dismissed and new elections called. The numbers on the electoral roll for each ward for this election in August 2004 are set out in Table 11.1. Clearly, the tenth ward, Anyungunba, which had not had members in the previous council, was not going to have members in the new council either, as the one person on the roll there could not self nominate. Woolla and Yanginj were also very low in numbers on the roll and it was known that these few enrolled people were not currently residing in the settlements. ${ }^{6}$

When the new council was elected in October 2004, it did, however, have a full complement of 18 members from nine wards, Anyungunba aside. None of the elections was contested, so it appeared that community discussion had delivered just the right number of nominees for vacancies. About half the members were returnees from the previous council, including the previous chairman and the one non-Indigenous member for the Ti Tree ward. At the first meeting of the new council, the previous chairman nominated again for that position, but so did a new member who had developed a working relationship with the new CEO as a liaison officer during the period after the dismissal of the previous council. This new council member won the position of chairman in a fairly close vote.

Table 11.1 ACGC Election 2004, enrolments by ward

\begin{tabular}{lr}
\hline Ward & Number Enrolled \\
\hline Alyuen & 20 \\
Anyungunba & 1 \\
Engawala & 57 \\
Laramba & 158 \\
Nturiya & 92 \\
Pmara Jutunta & 119 \\
Ti Tree & 109 \\
Wilora & 59 \\
Woolla & 14 \\
Yanginj & 8 \\
Total & 637 \\
\hline
\end{tabular}

Our relationship with the new council developed comfortably, though we moved away from using 'governance' as the key descriptive term for our project. The 'governance' terminology seemed to be associated with the idea of elected member 'training' of one sort or another, and we did not want to be cast in the role of a 'training' provider. We began to talk about 'working with Council' on 'issues

\footnotetext{
${ }^{6}$ Lack of current residence in these wards did not disqualify these enrollees from standing for office, as the formal criterion was one year's residence in the previous three.
} 
of importance or concern' to them, because we were interested in 'how' ACGC worked and, without pre-judging the matter, how it might work better.

The issue that emerged in late 2004 was the number of Aboriginal people camping informally along the western side of Ti Tree town, without reticulated water or electricity (see Fig. 11.2). The local member of the NT Legislative Assembly for Stuart, and senior Minister in the Martin Labor Government, Peter Toyne, had just written to ACGC expressing disquiet at the low level of servicing for significant numbers of campers in this area and asking whether ACGC might be able to do some more. ${ }^{7}$ ACGC agreed to run a boxed water service in the camps over the summer of 2004, funded by the NT Government, and we offered our services to do a study of who was living in the camps and for what reasons, and to report back to council. The camping seemed to be an 'issue of importance and concern' at least for Peter Toyne, and therefore also for the council.

Sarah Holcombe's chapter in this volume discusses in greater detail how this work proceeded, and we have also reported on it elsewhere (Holcombe and Sanders 2007; Sanders and Holcombe 2007). Suffice to say here, that the work proved a very useful way for us to get to know council members and their constituents, and for us to come to grips with life-ways and service patterns in the region. Declining service levels at Nturiya and places like Yanginj were clearly boosting numbers in 'Creek Camp', but so was trouble further afield, outside the Anmatjere region, in places like Willowra to the northwest. Among the 15 camps, which accommodated towards 100 people at times, there were about 25 very well established core, permanent residents. Some of these were public sector employees in Ti Tree, who were not offered housing with their employment. Employment-linked housing was restricted to senior employees mainly recruited from elsewhere. Two ACGC houses were available in Ti Tree for local Aboriginal employees, but this was far from enough, and one ACGC worker who had occupied one of these houses for a period had ended up living back in Creek Camp, sick of 'other people' using his 'lounge room as a bedroom'. There were also old and disabled people among the core residents of Creek Camp, who liked it as a quiet, spread out place to live, with dogs, close to town services and family, but away from the whitefellas of the compact eastern residential area and with a bit of service support from the Aged Care Day Centre. Most of the 25 or so core residents of Creek Camp saw themselves as continuing to live there for some considerable time, and were more interested in exploring development options there than the idea of moving into houses on the east side of Ti Tree (see Fig. 11.2).

\footnotetext{
7 Toyne had previously raised the issue of inadequate services for people camping in this area in the Legislative Assembly of the NT, soon after the closure of the community store at Nturiya (LANT 21 May 2002c: 1426).
} 
This last finding led us to explore the attitudes of other Ti Tree residents and NT Government officials to the idea of developing Creek Camp with reticulated services and possibly some buildings. Many were open to the idea, however, key interests within the NT Department of Planning and Infrastructure were not so keen and, in support of that stance, cited NT Government policy against the further recognition of Aboriginal community living areas in urban areas. The obstacles to reticulated services and other development at Creek Camp at this higher level of government seemed insurmountable, and ACGC itself also had some reservations, both on council and among its key managerial staff. So, after three reports to council over 18 months, we saw no option but to step back from this difficult issue for a while. Our probing had put a more positive and quantified image of Creek Camp in the public domain, but there was still no obvious way forward to ameliorate the existing situation.

In the middle of 2005, as we were first reporting to ACGC on the Creek Camp work, the one settler member of council resigned due to family commitments. Being replaced by an Aboriginal resident, council then became all-Aboriginal again, in a way that it had not been since 1995; and it has remained that way since. Late in 2005, council was once again dismissed for not meeting its quorum rule for two consecutive meetings. A new issue that was thus emerging was whether the quorum rule should be made less demanding. The 2005 council was reluctant to change the rule, with some of the long-serving members arguing that it was good to have people from all wards in the meeting when making decisions generally, but also that members from particular wards needed to be there for making decisions specific to their ward. Indeed, during 2005 we observed a tendency to defer to and support people from particular wards in decisions relating specifically to their wards.

For example, during 2005 the issue was often raised of reinvesting in electricity infrastructure at Yanginj and Woolla. Without residents permanently present, the generators in both places had gone missing over recent years. Some money was available for re-investment, but the CEO's argument was that, in order to safeguard assets, ACGC could only reinvest if there was some assurance of people residing in the two settlements. However, none of the four members of council from these two wards who were raising this issue could clearly commit to resuming residence themselves, or on behalf of members of their families. Other council members were generally supportive of their re-investment push, but essentially deferred on the matter to the ward members and the CEO. The issue gradually lost currency in council meetings as it became clear that the ward members could not commit to residence and the CEO was maintaining the need for such commitment in order to re-invest.

The new council that was elected in early 2006 only had 13 members from eight wards, nine of whom were returnees, including the chairman, and all of whom 
were, once again, elected unopposed. Woolla had no members in the new council, and Yanginj and two other wards had dropped down to just one member each, which potentially made meeting the quorum rule even harder, as these three single ward members had to be present at all meetings. We thought, at the time, that council was losing interest, as they were finding the CEO somewhat 'hard', even though procedurally he was scrupulous in keeping members well informed and involving them in decision making. ${ }^{8}$ Council members were also coming to understand that the CEO was a stickler for the rules, and we realised that probably in the past, the council had often not met its quorum rule, but that clerks and CEOs had simply not invoked the rules. ${ }^{9}$ Faced with this strict adherence to the rules and the prospect of being dismissed yet again, council began to shift, pragmatically, on the idea of changing the quorum rule. At the first meeting of the new council in February 2006, no quorum was achieved. At its second meeting in March, when a quorum was achieved, council passed a resolution that the quorum rule be changed to a simple majority of elected members. However, ACGC could only request such a change; the power to effect it lay with the NT local government Minister, and because of consultation requirements this would take some time.

From March 2006 onwards, the CEO seemed to soften somewhat. He gently let it be known that now that council had passed its resolution to have the quorum rule changed he would not dismiss it for not meeting the higher quorum rule - and in July 2006 this declared intention was indeed tested. After almost two years in the job, the CEO also seemed to be softening because he was benefiting from some build up of other managerial staff around him. A new social services director and staff were strengthening the level of ACGC activity in aged and disabled services, sport, recreation and youth services, and also child care services, not only in Ti Tree but in the outlying communities as well. The corporate services section had built a Rural Transaction Centre within the council office in Ti Tree and was increasing ACGC's level of both Centrelink and personal financial services. There was thus a sense that ACGC was growing and expanding its servicing roles a little, beyond electricity, water and housing, and back out from Ti Tree town into the outlying communities. This seemed to allow the CEO to relax a little with council and to take some credit for ACGC's modest recent expansion of services.

Another aspect of this expansion of service roles was that during late 2005 and early 2006, ACGC was being encouraged by the Commonwealth Department of

\footnotetext{
8 Folds (2001: 41) reports Indigenous views of managers being 'hard' in another NT Indigenous community governance context as follows: 'Managers who withhold "institutional" resources from Pintupi, as individuals, in order to fulfil their official purposes, are considered to be "hard" bosses, careless of relationships through their unreasonable greed'. Being a 'hard' and a 'good' manager in Indigenous community governance are related in quite complex ways (Sanders 2006a).

${ }^{9}$ Under changes to the NT Local Government Act, council clerks were redesignated as CEOs in 2003.
} 
Employment and Workplace Relations (DEWR) to become involved in running CDEP. This had two aspects. One was taking on the running of the existing CDEPs at Laramba and Engawala, and the second was developing CDEP for the first time in the settlements closer to Ti Tree. This second aspect was a substantial new opportunity for ACGC to offer quite large numbers of part-time jobs to local Aboriginal people in Pmara Jutunta, Nturiya, Ti Tree and Alyuen. This clearly had great potential for making ACGC more relevant and present in the lives of the residents of these settlements. However, the other aspect of ACGC taking on CDEP was somewhat more fraught, as it could easily be seen in Laramba and Engawala as ACGC muscling in on their long-standing, local, autonomous office and CDEP arrangements.

When DEWR awarded the CDEP contract for Laramba and Engawala to ACGC, the CEO knew that they would have to do some work allaying fears and building support in these communities. The local CDEP manager in each place, who doubled as a general office manager, would now for the first time become an ACGC employee, rather than being autonomously employed by a local committee. This new ACGC employee would clearly need to work with the local committees in these places if the new arrangement was to endure. Consequently, ACGC contracted the consultancy firm Burdon-Torzillo to do some 'CDEP governance' work in these two settlements, and we were encouraged to work with them. At the same time, an officer of the NT local government department was charged with the responsibility of consulting constituents about the proposed quorum rule change and helping the Minister ascertain that people were satisfied with it. We became adjuncts to both these processes, travelling frequently to Laramba and Engawala and less often to some of the other outlying settlements.

Our role in the quorum change consultations was educational. We developed some graphics to explain the proposed new quorum rule in comparison to the existing rule, one version of which was designed for notice boards and is reproduced in Fig. 11.3. These graphics seemed to work well as an educational tool and meant that the NT local government department officer had a sounder basis on which to assess that people understood and were supportive of the new rule. Like the Council, constituents seemed pragmatic about the rule change once they understood why council was being repeatedly dismissed. The Minister approved and promulgated the new quorum rule, which came into effect from November 2006. 
Fig. 11.3 Graphic of ACGC quorum rules

\section{Anmatjere Community Government Council Constitution, quorum rule change}

The Amatjere Council is incorporated under the NT Local Government Act.

Anmatjere Council has its own rules, these are called the constitution.

The constitituion says that the council is made up of 2 elected members from each of the 10 wards, or Community areas.

\section{What is a quorum}

A quorum is the number of members we need to hold a proper legal meeting and make decisions

Quorum rule NOW

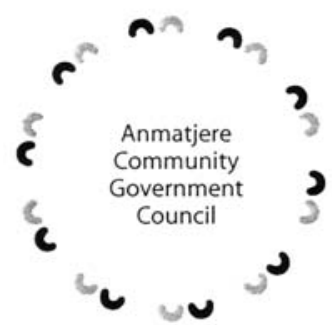

Now the constitution says we must have at least one member from each ward to hold a proper meeting.

If we can not hold 2 meetings in a row because we do not have a quorum the council is dismissed and we need another election

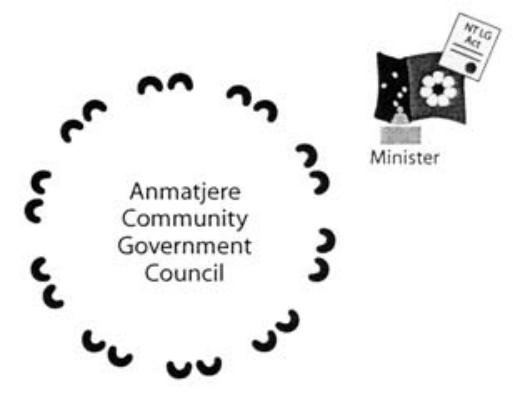

Quorum rule PROPOSED CHANGE

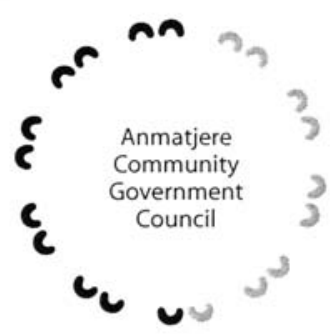

Because this has happened twice, we are asking the Minister to change the rule to:

That the quorum will be the majority (one more then half) of the elected members.

It will not matter which ward or Community they come from.

Source: Diagram developed by Burdon-Torzillo

Our role in the Laramba and Engawala 'CDEP governance' work was largely to assist Burdon-Torzillo in holding discussions with the 'committee' in these two settlements about the new administrative arrangements. In one of these settlements this meant meeting with a relatively small group of local people and in the other it meant large community meetings. In both settlements there were some fears about the changes to CDEP and local office staffing arrangements, but there was also a willingness to work with ACGC on refining the new arrangements. The main concern was to keep some degree of local settlement autonomy in the utilisation of the local CDEP workforce and equipment, and in the running of the local office and other local services. In light of this, Burdon-Torzillo developed the idea of local-regional agreements between ACGC 
and the two settlement committees, which would be signed by each (see Fig. 11.4). These agreements were developed during the second half of 2006 and signed in December. The significance of this work, however, was as much in the process as the product. The ACGC administration was showing considerable respect for single-settlement localism in dealing specifically with Laramba and Engawala in this way. Indeed, by the end of the process, the CEO was hailing Laramba and Engawala as ACGC's best organised settlements and wondering whether local committees and offices on other settlements could be usefully re-instituted as part of the introduction of CDEP.

Fig. 11.4 Depiction of regional/local relationships in Anmatjere (Source:

Burdon-Torzillo)

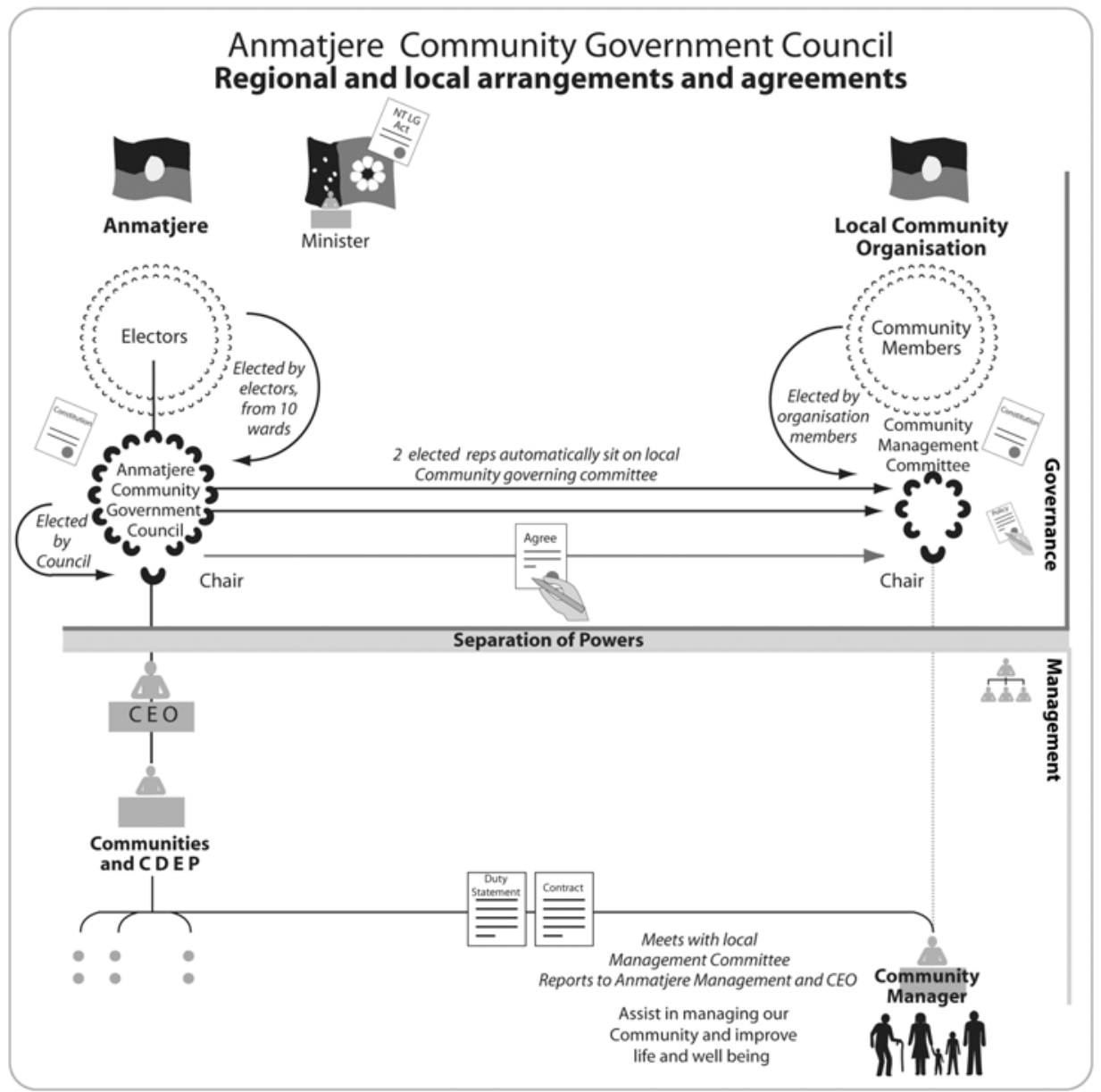

In the later months of 2006, an old settlement office in Pmara Jutunta was indeed refurbished and re-opened as part of the introduction of CDEP. A non-CDEP, settler staff member of ACGC was out-posted to this office for administrative 
and logistical support, commuting out daily from Ti Tree. A Pmara Jutunta settlement committee was also encouraged and established among CDEP participants, though with a broader remit than just helping organise CDEP in the settlement. Our next 'research' task, looking forward to 2007, was identified as supporting and working with this committee and the out-posted ACGC officer, helping them to address Pmara Jutunta settlement issues and to liaise with council regionally. ${ }^{10}$ There was also the suggestion that a similar arrangement might be developed at Nturiya, though that settlement no longer had an old office that could be easily refurbished, nor as yet, a coherent group of CDEP workers who could be drawn on to develop a settlement committee.

At the end of 2006, therefore, ACGC seemed to have rediscovered the need to support strong single-settlement localism within its larger multi-settlement regionalism. This seemed to us a very positive development that in some ways revisited the guarded regional federalism of ACGC's early constitutional design. Laramba and Engawala, rather than being seen as troublesome regional outliers, were now being recognised anew for their autonomous settlement strength. The introduction of CDEP to other ACGC settlements was being seen as an opportunity to reinvigorate their single-settlement strength as well, within the larger regional framework.

\section{Times of change: working with ACGC in 2007}

The year 2007 was looming as one of quite considerable change for ACGC. Towards the end of 2006, the CEO had let it be known that he was intending to move on at the expiry of his three-year contract in April 2007, and was therefore instituting a process for recruiting his successor.

Also in October 2006, after many months of rumours, the NT's new, and second Aboriginal local government Minister, The Hon. Elliot McAdam, had announced that there was about to be another round of local government reform. The new framework was to develop municipalities and 'regional shires' that would cover the entire Territory from July 2008, rather than just the piecemeal incorporation of about eight per cent of its land area as under the existing arrangements. While the number of municipalities and shires was not specified, the Minister had stated that:

\footnotetext{
${ }^{10}$ Having moved away from the language of 'governance' to describe our own task and tried the phrase 'issues of importance or concern', we realised in time that council members were simply using the words 'research' and 'researchers' to describe our role. Hence once, when introducing us to a third party, the ACGC Chairman commented: 'We like our researchers, they came with a blank page'. The idea that council could experience 'research' and 'researchers' as similar, irrespective of their substantive interest, and that 'good researchers' are those whose substantive interests are flexible enough to recede from view, raises interesting implications for engagement between academics and Indigenous organisations.
} 
it is evident from research undertaken on the sustainability of local governments in other jurisdictions that a shire of less than 5000 people would struggle to be sustainable in the long term (McAdam 2006: 4).

Clearly, the intention was to move to larger groupings than at present, including for ACGC.

Then in January 2007, Minister McAdam announced that there would be just four municipalities and nine shires, and he published a map of their suggested boundaries (McAdam 2007; see Fig. 11.5). ACGC was to be combined with five other local governing bodies in a Central Desert Shire which would cover a band of land from the Queensland to the Western Australian borders north of Alice Springs. Central Desert Shire's constituency would be about 5,000 people.

A proposal of roughly this sort had been foreshadowed by the CEO at ACGC meetings during the later months of 2006, and when it was announced there was no great sense of surprise, or indeed of hostility, among members. Rather, there seemed to be a sense that restructuring local government is just something that higher levels of government do from time to time. There was also a sense that members would now wait, watch and gradually reposition themselves as the framework was further developed. We suggested that this development increased the importance of having local single-settlement committees operating, as when ACGC disappeared these might become a way in which people living in particular settlements could have some input to and influence on the shire. This diagnosis seemed readily accepted and reinforced the idea that our research task for 2007 would be to encourage and support the work of single-settlement committees.

Another unexpected source of change in March 2007 was the resignation of the ACGC Chairman of the previous two and half years. While the CEO, ourselves and others had all found him a capable and constructive colleague, there were some signs that the pressure of the job was taking a personal toll. Having been picked up by the police for a driving offence, it came to light that the Chairman was still on parole for a more major past offence and should not, by the rules, have been on council for the past two and a half years anyway. The Chairman resigned from council and his younger deputy was thrown into the role of Acting Chairman at precisely the time when the recruitment of the new CEO was reaching its conclusion. 
Fig. 11.5 Proposed shires and municipalities in the Northern Territory from July 2008

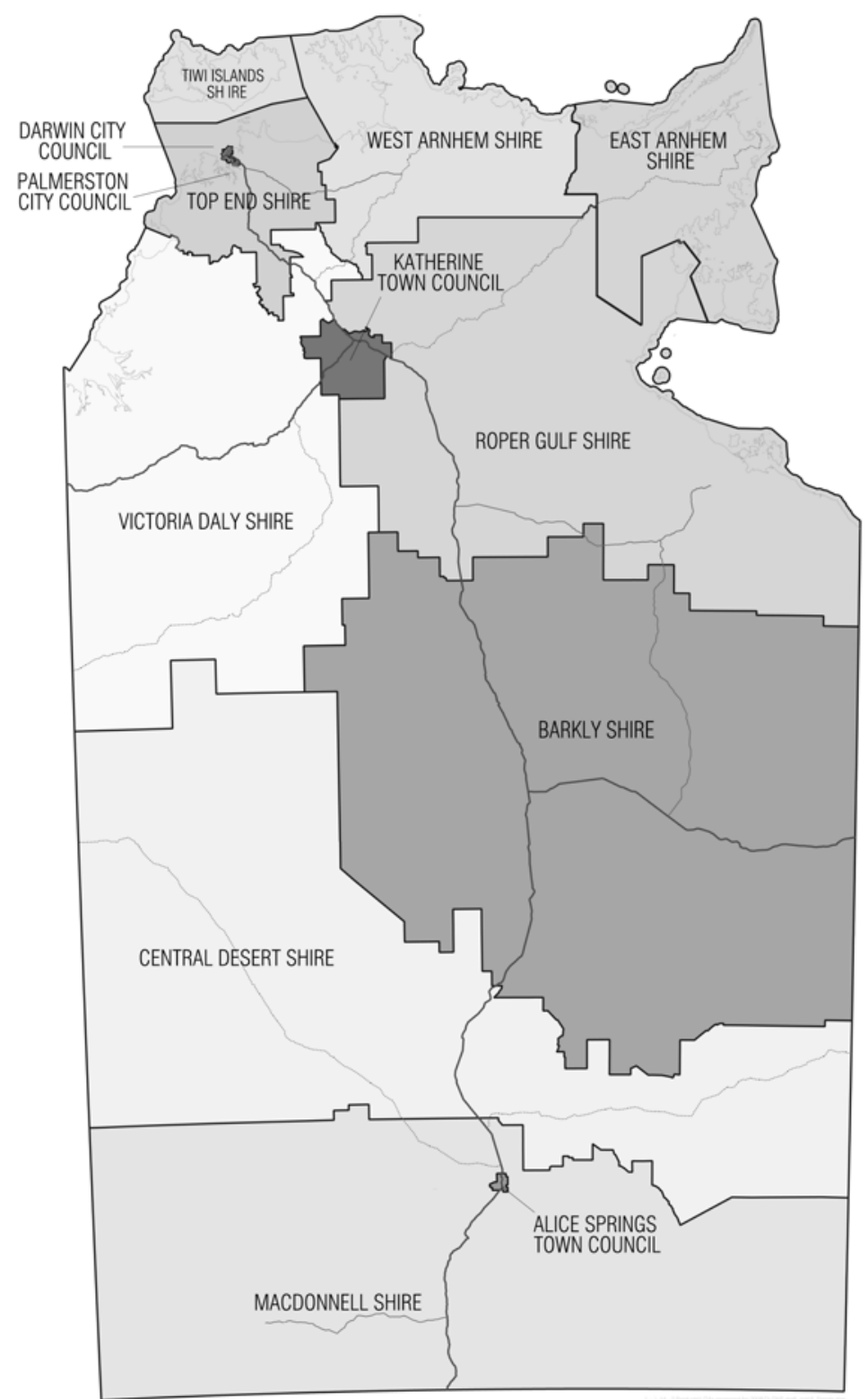


All this was, in fact, handled very smoothly during March 2007, and by the April council meeting both a new CEO and a new Council Chairman were in place. The new Chairman was the previous deputy and the new CEO a woman who had served in a senior managerial post within ACGC for a period of eight months in 2006. There was, thus, a very strong element of continuity in the leadership change at ACGC in April 2007. However, the new CEO clearly also had ideas for change based on her past experience and the new, younger Chairman was also going to put his own stamp on the job.

The final source of change for ACGC in 2007 was the Howard Commonwealth Government's 'national emergency' intervention into NT Aboriginal communities, which was announced on June 21 . This comprised 11 areas of proposed change, ranging from alcohol restrictions and compulsory income management in prescribed areas to health checks, increased numbers of police, Commonwealth leases and the end of the permit system in settlements on Aboriginal land, plus the appointment by the Commonwealth of Government Business Managers (Brough 2007). A month later, the intended abolition of the CDEP scheme in the NT over the next year was also announced as a twelfth intervention measure (Brough and Hockey 2007; see also Chapter 2, this volume).

This last intervention measure, in particular, clearly had major implications for ACGC and its growing network of local offices and committees in its discrete Aboriginal settlements. Initially, ACGC was given a CDEP closure date of late October 2007 and informed that participants should be sent on leave before then to serve out their annual leave entitlements. However, in early October ACGC was given a revised CDEP closure date of February 2008. This possibly reflected lobbying from ACGC for the maintenance of CDEP, but also that closures of CDEPs south and west of Alice Springs had been somewhat contested and difficult, and were taking longer than anticipated.

With the defeat of the Howard Coalition Government in November 2007 and the election of the Rudd Labor Government on a platform of continuing the intervention, but reviewing it after 12 months, and of reforming rather than abolishing CDEP, this foreshadowed closure of CDEP in February 2008 has not proceeded. So, the role of CDEP in helping ACGC maintain and develop local settlement offices and committees looks likely to continue until ACGC itself disappears in mid 2008.

On the other intervention measures, ACGC was informed during October 2007 that the Commonwealth now had a lease over at least some of its outlying discrete Aboriginal communities and that it should 'continue to operate' its 'housing service according to existing policies and requirements' until contacted by the relevant Commonwealth department. It was also informed that an Australian Government Business Manager would be starting work in the region from October 
29. ${ }^{11}$ From the perspective of the ACGC CEO, however, little had resulted from the intervention by that time, except for uncertainty about the future of CDEP and demands for a large number of meetings with visiting Commonwealth officers. No new resources had flowed to ACGC as a result of the intervention.

The larger prospect of change for ACGC at the end of 2007 was still dominated by its foreshadowed amalgamation into Central Desert Shire in the middle of 2008. The ACGC Chairman, CEO and one other councillor had attended shire transition committee meetings during 2007, and a number of decisions had been made. The Anmatjere region will be one of four wards within the Central Desert Shire, with four representatives out of 12, calculated on a rough population basis. The shire is to be headquartered outside of its own boundaries in Alice Springs, though there will still be substantial offices focused on service delivery in each of the four wards. Hence, the large ACGC office complex and Council Chambers in Ti Tree will be a shire branch office, rather than a headquarters, even though $\mathrm{Ti}$ Tree is geographically quite central within the Central Desert Shire and there was some debate in the transition committee about possibly having a headquarters within the shire. These are major changes for Ti Tree and the Anmatjere region, which after 15 years of having its own distinctive regional, multi-settlement local government is about to lose it.

\section{Achievements and limitations: from Anmatjere Community Government Council to Central Desert Shire}

I began this chapter by noting how ACGC emerged out of an attempt by the NT Government to encourage regional up-scaling in its local government system and now, 15 years later, how it is set to disappear into the much larger Central Desert Shire as part of another such local government up-scaling exercise. In this final section I will reflect more generally on both ACGC's achievements and its limitations during its 15 year life. I will also speculate a little on how Central Desert Shire might further develop local governance in this region, pointing to differences with ACGC as well as similarities.

ACGC's major achievement of the last 15 years has been holding together and providing basic services to a disparate group of discrete Aboriginal settlements in the Anmatjere region. Though there has at times been tension within the group, none of the settlements has in fact broken away from ACGC. Three of the smaller settlements appear to have withered over this period, but the six other settlements have endured in a useful, and respectful, small regional federation. The level of servicing that ACGC has been able to provide to these enduring settlements has sometimes been rather basic, covering just water, electricity and housing. But, over time, ACGC has also built up its presence in

\footnotetext{
11 This information was contained in letters to ACGC tabled at the monthly meeting on 24 October 2007.
} 
social services, such as aged care, child care and youth, sport and recreation, as well as in Centrelink support and personal financial services. Since 2006, ACGC has also been able to increase its contribution in the region as a provider of base-level, part-time employment for Aboriginal people through the CDEP scheme. These are modest, but by no means insubstantial achievements for a regional local government in a remote area of the NT.

In the period that Sarah Holcombe and I have observed, ACGC also appears to have overcome some of the worst problems of 'isolated managerialism', whereby very small organisations that rely on just one or two managerial staff, periodically collapse through the departure of a key person. In 2007, we observed an orderly transition from one CEO to the next at ACGC. More generally over the four years, we have also observed a high degree of administrative continuity at ACGC through a managerial team which, at any one time, numbers more like seven or eight people, rather than just one or two. The period that we have observed may not be entirely typical, as in the seven years from 1997 to early 2004, ACGC had six Council Clerks or CEOs, most of whom stayed less than a year. This rate of turnover of senior managers is somewhat worrying, but there does seem to have been basic continuity of administration in ACGC and, as the period 2004-07 has demonstrated, managerial stability can indeed be achieved in an organisation the size of ACGC.

Against these two basic achievements, there can I think be counter-posed an essential failing or limitation of ACGC, which is that it never really achieved a coming together of Aboriginal and settler interests in the Anmatjere region. Such a coming together of interests was certainly the intention of the NT Government when it pushed Ti Tree town and its Progress Association into ACGC in 1995. However, the settler interests of Ti Tree town went into ACGC somewhat unwillingly and have perhaps never really been entirely comfortable within it. I have noted above that in the early days of the research there was one settler member of ACGC for the Ti Tree town ward, but that in mid 2005 this member withdrew due to family commitments and that since then council has been all Aboriginal. Holcombe and I are also aware that in the late 1990s there was another active settler member on council, but by the time of our engagement in 2004 that person had not only left council, but also left town. Hence, there is a sense in which settler interests, as elected members, seemed to withdraw from ACGC after a while, possibly because they found its predominance of Aboriginal members and concerns quite difficult to engage with. ${ }^{12}$

\footnotetext{
12 This is a speculative comment that suggests a hypothesis to be investigated as much as an argument for which I am giving evidence. Neither Holcombe nor I have had contact with the settler member of ACGC from the 1990s and have only heard of his supposed frustrations with council second hand. The settler member whom we observed in 2004-05 has always emphasised family commitments as the reason for withdrawal.
} 
This limitation of ACGC might seem counter-intuitive in light of our Creek Camp work. For in many ways the central story of that work was that a historical pattern of residential segregation between settler and Aboriginal people in the Anmatjere region was being maintained. Ti Tree town was still essentially the residential area for settlers and Aboriginal people were still generally encouraged to reside in outlying settlements. The fact that ACGC, as the local government body, had predominantly Aboriginal members somehow had not greatly changed this historical pattern of residential segregation. Settler interests still dominated in Ti Tree town, partly through the policies and influence of certain departments of the NT Government. However, ACGC members were also quite hesitant and unsure about whether and how this pattern of residential segregation might change.

Nevertheless, it was the case that settler interests tended to leave the role of elected representatives on ACGC to Aboriginal interests, and that ACGC did not, as a result, realise its full potential as a local governing body that brought together Indigenous and settler interests. One reviewer of an earlier draft of this paper noted that Holcombe and I were undertaking this research as part of an Indigenous community governance project and wondered whether we thought local government was in fact an appropriate vehicle through which Aboriginal people could work. ${ }^{13}$ My approach has long been that Aboriginal people can and should be able to take opportunities to participate in general political institutions, like local government, as well as Aboriginal-specific organisations, like land councils (Sanders 1996). In a geographic region like Anmatjere, in which over 80 per cent of the resident population is Aboriginal, there is clearly a very good electoral base from which Aboriginal people can participate in general political institutions, and this in no way restricts their ability to also participate in Indigenous-specific institutions.

Under the Central Desert Shire, the issue of mixing Indigenous and settler interests will no doubt arise anew, both in the Anmatjere ward and in the other three wards to the west and east. As it incorporates all land areas, Central Desert Shire could potentially draw in more settler interests than ACGC ever could or did. However, with a constituency that is also over 80 per cent Aboriginal, it is possible that settler interests will also stand back from the Central Desert Shire and that it too will fail to be a meeting place for Indigenous and settler interests in quite the way hoped for by the NT Government. In a sense, what the history of ACGC demonstrates, and what Central Desert Shire may yet in time also demonstrate, is that it is very hard in remote areas of the NT to genuinely combine Indigenous and settler interests in one local government organisation.

\footnotetext{
${ }^{13}$ This issue also came up at the very first council meeting we attended, when the CEO noted that ACGC was not an Indigenous-specific organisation. We acknowledged this, but argued that Indigenous community governance should also be seen as covering situations like ACGC's.
} 
The Central Desert Shire may also face a greater challenge than ACGC even in just bringing together Indigenous interests. Whereas ACGC was named after a single Aboriginal language group, Central Desert Shire also covers the Warlpiri to the west and the Alyawarr and Eastern Arrernte language groups to the east. As well as straddling these four language groups, Central Desert Shire will cover discrete Aboriginal settlements that are over $1000 \mathrm{~km}$ apart, rather than just 100 or $200 \mathrm{~km}$ apart as in ACGC. Travelling to centrally located council meetings will be a matter of days, rather than hours, and feeling common interests over such substantial geographic and social distances may also be a considerable challenge. So, Central Desert Shire may need to work even more assiduously than ACGC in bringing together the Indigenous interests of its larger geographic area, and in developing a multi-settlement regionalism that respects and builds on single-settlement localism.

The fundamental argument of this chapter, however, is that ACGC has shown that regional, multi-settlement local government in the remote areas of the NT can survive, can provide representation for diverse Indigenous interests and can offer its residents some useful services, if it respects and builds on the strengths of single-settlement localism. ACGC, as a regional, multi-settlement local government, has worked best when it has valued its constituent settlements for their autonomous, local strength and has worked with them cooperatively. Whether Central Desert Shire will be able to do likewise, across a far larger regional grouping, will only emerge over time and will be of considerable interest to observe.

\section{Postscript}

In February 2008, the new Henderson Labor Government in the NT pulled back a little from some of this fore-shadowed local government reform. It announced that the proposed Top End Shire, in the Darwin hinterland, would not proceed and that existing local governments in that area would remain. However, further afield, in remoter areas with fewer settler interests and more predominantly Aboriginal populations, reform of local government was to proceed as planned (Henderson 2008). This change of heart led the Aboriginal local government Minister, The Hon. Elliot McAdam, who had initiated the reform proposal back in late 2006 and early 2007, to resign from the cabinet and ministry. A new non-Indigenous Minister will now oversee the completion of the process.

In Anmatjere and the larger Central Desert Shire area, the local government reform process still looks likely to proceed. Indeed, in February 2008, the new ACGC CEO of 10 months standing left to take up a position in the newly emerging MacDonnell Shire to the south. The new shires were thus beginning to have an effect, simply by drawing experienced managers out of the existing local governments. Administrative continuity was, however, once again maintained 
at ACGC in February 2008, as the existing social services manager took on the job of CEO for the final four months of its existence.

With all its achievements and limitations, ACGC now seems destined to disappear from the landscape of NT local government in mid 2008. Hopefully, ACGC will be remembered as a modestly successful experiment in multi-settlement regionalism, which respected and built on single-settlement localism.

\section{Acknowledgements}

As well as being part of the ICGP supported by the Australian Research Council and Reconciliation Australia under Linkage Project No. 0348744, this work has also been supported by the Australian Government Cooperative Research Centres (CRCs) Programme through the Desert Knowledge CRC, at first through its Governance Theme and later through its Core Project on Sustainable Desert Settlements. The views expressed herein do not necessarily represent the views of the Desert Knowledge CRC or its participants.

\section{References}

Ah Kit, J. The Hon. 2003. 'Building stronger regions - stronger futures', Address as NT Minister for Community Development to the Local Government Association of the Northern Territory, 14 May, Alice Springs.

Brough, M. The Hon. 2007. 'National emergency response to protect Aboriginal children in the $\mathrm{NT}^{\prime}$, Media Release by Minister for Families, Community Services and Indigenous Affairs, Australian Government, 21 June, available at <http://www.facsia.gov.au/internet/minister3.nsf/content/ emergency_21june07.htm $>$.

and Hockey, J. The Hon. 2007. 'Jobs and training for Indigenous people in the $\mathrm{NT}^{\prime}$, Joint Media Release by Minister for Families, Community Services and Indigenous Affairs and Minister for Employment and Workplace Relations, Australian Government, 23 July, available at $<$ http://www.facsia.gov.au/internet/minister3.nsf/content/cdep_23jul07.htm>.-

Campbell, D. 2001. 'Double exposure: the story of the formation of the Tiwi Islands Local Government', Research paper prepared for the Department of Community Development, Sport and Cultural Affairs, Local Government and Regional Development Division, NT Government, Darwin.

Coburn, W. 1982. 'Aboriginal community councils and the delivery of services', in P. Loveday (ed.), Service Delivery to Remote Communities, NARU Monograph, North Australia Research Unit, ANU, Darwin.

Folds, R. 2001. Crossed Purposes: the Pintupi and Australia's Indigenous Policy, University of New South Wales Press, Sydney. 
Henderson, P. The Hon. 2008. 'Local government changes', Media Release by Chief Minister, Northern Territory Government, 12 February, available at $<$ http://newsroom.nt.gov.au/index.cfm?fuseaction=viewRelease $\&$ id $=$ $3598 \& d=>$.

Holcombe, S. and Sanders, W. 2007. 'Accommodating difference? The socio-politics of an Aboriginal fringe camp in a small north Australian town', The International Journal of Interdisciplinary Social Sciences, 2: $339-48$.

Legislative Assembly of the Northern Territory (LANT). 1993a. Parliamentary Record No. 16, Sixth Assembly, First Session, 26 May 1993, Darwin. 1993b. Parliamentary Record No. 17, Sixth Assembly, First Session, 29 June 1993, Darwin.

1995a. Parliamentary Record No. 14, Seventh Assembly, First Session, 22 August 1995, Darwin.

1995b. Parliamentary Record No. 14, Seventh Assembly, First Session, 23 August 1995, Darwin.

1999. Parliamentary Record No. 14, Eighth Assembly, First Session, 17 February 1999, Darwin. 2002a. Parliamentary Record No. 3, Ninth Assembly, First Session, 28 February 2002, Darwin.

2002b. Parliamentary Record No. 3, Ninth Assembly, First Session, 7 March 2002, Darwin.

-2002c. Parliamentary Record No. 4, Ninth Assembly, First Session, 21 May 2002, Darwin.

2003. Ministerial Statement, Building Stronger Regions - Stronger Futures, Parliamentary Record No. 6, Ninth Assembly, First Session, 20 August 2003, Darwin.

McAdam, E. The Hon. 2006. 'Minister's Speech' as Minister for Local Government, Local Government Association of the Northern Territory (LGANT) Conference, 11 October, Alice Springs, available at $<$ http://www.localgovernment.nt.gov.au/new/minister/ministers_speech $>$.

McAdam, E. The Hon. 2007. 'New local government structure announced', Media Release by Minister for Local Government, Northern Territory Government, 30 January, available at $<$ http://newsroom.nt.gov.au/ index.cfm? fuseaction $=$ viewRelease $\& i d=1319 \& d=5>$.

Morton, J. 1994. The Proposed Anmatjere Land Council: Its Historical Antecedents and an Estimation of Levels of Support, Unpublished report to ATSIC, Canberra. 
Northern Territory Government 2003. Building Stronger Regions-Stronger Futures: Northern Territory, Department of Community Development, Sport and Cultural Affairs, Darwin.

Phegan, G. 1989. 'Community government models for small towns in the Northern Territory', in P. Loveday and A. Webb (eds), Small Towns in Northern Australia, NARU Monograph, North Australia Research Unit, ANU, Darwin.

Sanders, W. 1996. 'Local governments and Indigenous Australians: developments and dilemmas in contrasting circumstances', Australian Journal of Political Science, 31 (2): 153-74.

-2005. 'Dispersal, autonomy and scale in Indigenous community governance: some reflections on recent Northern Territory experience', Australian Journal of Public Administration, 64 (4): 53-62.

-2006a. 'Being a good senior manager in Indigenous community governance: working with public purpose and private benefit', CAEPR Discussion Paper No. 280, CAEPR, ANU, Canberra.

2006b. 'Local governments and Indigenous interests in Australia's Northern Territory', CAEPR Discussion Paper No. 285, CAEPR, ANU, Canberra.

— and Holcombe, S. 2007. 'The Ti Tree Creek Camp study: a contribution to good governance', Ngiya: Talk the Law, 1: 71-91.

Wolfe, J. 1989. 'That Community Government Mob': Local Government in Small Northern Territory Communities, North Australia Research Unit, ANU, Darwin. 